\title{
Integrating One of Internal Structure of Discourse Called 'Process' in Writing Procedure Text for Intermediate Level
}

\author{
Emilia Widuri \\ English Education Department, Post Graduate Program, Yogyakarta State University \\ Emai: emilia.widuri2016@student.uny.ac.id
}

\begin{tabular}{l}
\hline Article Info \\
\hline Article history: \\
Submitted Dec 31, 2017 \\
Revised April 4, 2018 \\
Accepted April 8, 2019 \\
Published April 10, 2019 \\
\hline
\end{tabular}

\section{Keywords:}

Discourse analysis, Internal structure, Procedures text

\begin{abstract}
In this article the researcher applies one of internal structure of discourse called 'Process' in writing 'Procedures text'. Procedure text is a piece of writing that tells us information of making/doing something through several steps/directions. There are two important parts that students have to consider in procedure text; the generic structure and the language features. In the language features, the internal structure of "Process" of discourse integrated. The aim of internal structure of "Process" are offers the procedure/process for how something is done/created. The problem occurs when students ignore the internal structure of discourse, therefore they will face difficulties in writing process. The first step of the researcher did in this research was making a lesson plan and student' assessment. After finish it the researcher discussed with the expert to get the feedback. Based on the feedback the researcher revised it. Once again researcher discussed with the expert to get the final result of lesson plan and student' assessment. The next step was conducting try out. It was held on 28th December 2017. The subjects are 3 students of UNY. The subjects are chosen randomly. Based on the research finding, internal structure is applicable in writing. The generic structure and language features are also really helpful for students in writing English especially procedures text. Thus, all of the subjects of the research be able to produce discourse part with the same structure and successfully produce a paragraph of procedure text.
\end{abstract}

\section{Corresponding Author:}

Emilia Widuri,

English Education Department, Post Graduate Program,

Yogyakarta State University, Yogyakarta, Indonesia

Email: emilia.widuri2016@student.uny.ac.id

\section{INTRODUCTION}

Cook, G. (1989) points out discourse analysis as examines how stretches of language; considered in their full textual, social, and psychological context, become meaningful and unified for their users. Furthermore, he also correlates the theory of discourse analysis to demonstrate its practical relevance to language learning in teaching. The problem occurs when students ignore the internal structure of discourse, therefore they will face difficulties in writing process.

The purpose of the study is integrating one of internal structure of discourse in teaching writing of procedures text. Therefore, students will be able to explore internal structure of discourse part and lead them to produce part with the same structure, especially in the procedures text. Cook, G (1989:99) mentions that many text book do show awareness of the need to deal with different discourse types, but few confront the issues of identification. Here by, students need to recognize the internal structure of discourse and apply it in writing. By doing so, hopefully there will be improvement on their writing ability.

The method of the current study is an interpretive case study. Mc Donough (1997) states that in interpretive case study, the researcher aims to interpret the data, by developing conceptual 
categories supporting or challenging the assumptions made regarding them. Furthermore, Creswell (2005) believes that a case study is a qualitative research that focuses on providing an in depth understanding about a problem. Shuttleworth, M (2008) also points out that a case study is an in depth study of a particular situation rather than a sweeping statistical survey. It is a method used to narrow down a very broad field of research into one easily researchable topic. Whilst it will not answer a question completely, it will give some indications and allow further elaboration and hypothesis creation on a subject. The case study research design is also useful for testing whether scientific theories and models actually work in the real world. This currents study also classified in an instrumental case study. According to Stake (1995), instrumental case study is when researcher selects a small group or subjects in order to examine a certain pattern behaviour, in this case is integrating internal discourse structure in teaching writing.

\section{THEORY AND METHODS}

Discourse structure is the way the text is organized. They are internal and external structure in discourse. Internal text structure is basically the generic structure of the text which determines the rhetorical steps or strategies for composing such text. Internal structure consists of several factors such as: Cause and Effect, Comparison/ Contrast, Enumeration or Listing, Sequential or Chronological, Concept/ Definition, Generalization, Process. Whilst External text structures can help students read and understand informational (or expository) text. External structure consists of: Table of contents, Headings, Bold or italicized words, Graphics/illustrations, Footnotes. In this research, the researcher will apply one of internal structure of discourse called 'Process' in teaching writing of 'Procedures text'. The characteristics of process are using several signal words such as Step one or First, Next, then; begins with, in order to, and so on. The aim is the writer offers the procedure or process for how something is done/created. The text usually finds in cook book or manual book.

Procedure text is one of the texts in genre based approach. The text is a piece of writing that tells us information of making or doing something through several steps or directions. The example of procedure texts includes cooking recipes, direction to find a place, rules game, manual instructions of a tool, science experiment. In addition, there are two important parts that students have to consider, they are the generic structure and the language features of procedure text. The generic structure of procedure text divided into three parts, such as goal, ingredients or material and method or steps. Goal or purpose in procedural text describes someone wants to do. It usually states in the title of the text. Furthermore, material or ingredients are things to be prepared. Method or steps provide sequence step in making or doing something. The language features that usually used in writing procedural text are in the form of simple sentence, use many action verbs for command (stir, chop, cut), use present tenses and use linking words (first, then, last). In the language features, the internal structure of "Process" of discourse integrated. The aim of internal structure of "Process" are offers the procedure or process for how something is done/created.

Feez \& Joyce (1998: 27) explain that there are four stages in teaching learning cycle using the genre approach, especially for procedures text, they are: (1) Building Knowledge of the Field: In this stage, the teacher tries to develop students' prior knowledge of procedure text by doing brainstorming. Here, teacher asks some questions based on the topic which related to the procedure text, (2) Modeling of the text: In this stage, teacher tries to develop students' understanding of procedure text from its feature and purpose. Here, teacher give the text example as the text model. Then, ask the students to read and explore. Finally, teacher and students try to analyze the structural pattern and language features of the model text. They will also try to compare the model text with other examples of the text-type, (3) Joint construction of the text: In this third stage, teacher tries to develop students' writing skill to make procedure text. Students here start to have group discussion related to the text. Doing some activities such as writing the generic structure of the text and the features of the text will help students in their writing development, (4) Independent construction of the text: The fourth stage lead students to have independent activities. They will construct (write) a text that is being studied independently, for 
example. Here, teacher tries to develop students' writing skill to produce procedure text individually based on their generic structure and text features.

\section{FINDING AND DISCUSSION}

\section{a. Discussion}

The first step of the researcher did was making lesson plan and student' assessment. After finish it the researcher discussed with the expert to get the feedback. Based on the feedback the researcher revised it. Once again researcher discussed with the expert to get the final result of lesson plan and student' assessment. After finishing the lesson plan and student' assessment, the next step was conducting try out. It was held on $28^{\text {th }}$ December 2017 . The time was at 01. 00p.m until 02.00p.m.

The subject of the study is 3 students of Yogyakarta State University. They are Eki, Selamet, and Muza. Eki is an undergraduate student of economy major semester seven. She is 21 years old. Selamet is a master degree student of English education semester one. He is thirty-two years old. Whilst Muza also a master degree student of English education semester one. He is thirty-two years old. The subjects are chosen as random sampling of UNY students in this study case. The consideration to use random sampling of UNY students because their English ability are in intermediate level which suitable with the lesson plan level. Another consideration is for research economically and time efficiency.

b. Finding

The research purpose of the study is integrating one of internal structure of discourse in teaching writing of procedures text. Therefore, students will be able to explore internal structure of discourse part and lead them to produce part with the same structure, especially in the procedures text.

From the student' assessment the findings are as follow:

\begin{tabular}{|l|}
\hline First Subject: Eki Sulistyawati \\
\hline Assessment number 1 \\
In assessment number 1 student needed to analyse the structural pattern and language \\
features of two procedures text. In text 1 and 2 the subject did not meet any difficulty \\
and be able to finish the task well. She did not make any mistakes in this task. \\
Assessment number 2 \\
In assessment number 2 student needed to write generic structure and language \\
structure that they made by them self. In this task the subject did not meet any \\
difficulties even though she was non-English major student. It was proven with there \\
was no mistake she made in the task. \\
Assessment number 3 \\
In assessment number 3 student needed to write a procedure text based on their \\
generic structure and language structure they produced. In this task the subject did not \\
meet any difficulty. She was able to arrange the procedure text into good paragraph. The \\
only unsuitable she made was repeated the word 'then' twice. Grammatically it was \\
correct, but as discourse it was not suitable diction in procedure text.
\end{tabular}

Second Subject: Selamet Riadi

Assessment number 1

In assessment number 1 student needed to analyze the structural pattern and language features of two procedures text. In text 1 and 2 the subject did not meet any difficulty and be able to finish the task well. He did not make any mistakes in this task. 
Assessment number 2

In assessment number 2 student needed to write generic structure and language structure that they made by them self. In this task the subject did not meet many difficulties. The only difficulty was the subject forget some vocabularies that seldom to use in English such as gula jawa: palm sugar, santan kelapa: squeezed coconut milk. The subject was mistaken wrote 'than' instead of 'then'.

Assessment number 3

In assessment number 3 student needed to write a procedure text based on their generic structure and language structure they produced. In this task the subject did not meet any difficulty. He was able to arrange the procedure text into good paragraph. The only mistake he wrote 'than' instead of 'then' and incorrect of infinite 'the' in the sentence

\begin{tabular}{|l|}
\hline Third Subject: Muzayyin Habibi \\
\hline Assessment number 1 \\
In assessment number 1 student needed to analyse the structural pattern and language \\
features of two procedures text. In text 1 and 2 the subject did not meet any difficulty \\
and be able to finish the task well. He did not make many mistakes in this task. The only \\
one mistake was the subject forget to put preference word such as 'otherwise' and 'or' in \\
the generic structure of text 2 . \\
Assessment number 2 \\
In assessment number 2 student needed to write generic structure and language \\
structure that they made by them self. In this task the subject did not meet any difficulty. \\
Assessment number 3 \\
In assessment number 3 student needed to write a procedure text based on their \\
generic structure and language structure they produced. In this task the subject did not \\
meet any difficulty. He was able to arrange the procedure text into a good paragraph. \\
The only mistake he made was did not need to write 'then' in the last sentence of that \\
paragraph.
\end{tabular}

\section{CONCLUSION}

The research purpose of the study was integrating one of internal structure of discourse in teaching writing of procedures text. The internal structure was 'process'. By doing so, students would be able to explore internal structure of discourse part and lead them to produce part with the same structure, especially in the procedures text. Based on the research finding, internal structure of process and the part of it was applicable in writing a procedure text. Furthermore, the generic and language structure are really helpful for student in writing English especially procedures text. From this research, all of subjects were successfully apply without many difficulties they met. They also were able to produce the discourse part with the same structure. The result would be different if they did not use internal structure of discourse, because the generic structure and language structure were really helpful for them to sequence the process in procedures text. The internal structure of process also helped them much in arrange the writing idea to be cohesive, coherence, and comprehensible paragraph. Thus, the researcher concluded that discourse pedagogical discourse analysis. 


\section{REFERENCES}

Cook, Guy. (1986). Discourse. New York: Oxford University Press

Creswell, J.W. (2009). Educational research. (2nded). Upper Saddle River, N.J: Pearson Education.

Feez, S. \& Joyce, H. (1998). Text-based syllabus design. Sydney: Macquarie University/AMES

Greene et al. (2005). Research method in the educational science. SAGE Publications Ltd: London.

McDonough, P.M. (1997). Choosing colleges: How social class and schools structure opportunity. Albany: State University of New York Press.

Online Retrieved:

www.lcps.org

http://www.ibpublishing.ibo.org

Martyn Shuttleworth (Apr 1, 2008). Case Study Research Design. Retrieved Dec 08, 2017

from Explorable.com: https://explorable.com/case-study-research-design 